Session 3533

\title{
Improvements in Electric Power Systems Curricula: Developing Continuous Improvement Plan
}

\author{
Ilya Grinberg, John A. Stratton, Frank Pietryga, and James Maxwell \\ Buffalo State College/ Rochester Institute of Technology/ University of Pittsburgh - \\ Johnstown/ Buffalo State College
}

Faculty at three universities in the New York / Pennsylvania region offer their engineering technology students required or elective sequences in electric power systems. The three institutions were each looking at possible changes to their respective courses to make them more relevant to the power systems industry which is struggling to assure reliable and economic delivery of power in the light of deregulation and the blackouts of the recent past.

The authors are looking at TC2K Criteria Elements, such as program educational objectives, program outcomes, assessment and evaluation, as well as program characteristics. All these components are compared between three universities. Methodology for continuous improvement is proposed based on the results of the study.

The four faculty compiled the results of the surveys and determined which input was most valuable to each university, comparing the various metrics which were available.

Materials Developed for TAC of ABET

Buffalo State College (BSC) and Rochester Institute of Technology (RIT) were both re-visited by TAC of ABET in the Fall of 2004. Their materials are included from those used in the self-study process for their first TC2K visit. The University of Pittsburgh at Johnstown (UPJ) has not yet been visited since TC2K has been in force. Their materials are based on their internal continuous improvement process.

Program Educational Objectives (PEO’s)

The TAC of ABET defines these as very general objectives which alumni should have achieved after a few years of employment in industry. The following is a summary of the PEO's, which the EET programs at each of the three universities have included:

\begin{tabular}{|l|l|l|l|}
\hline $\begin{array}{l}\text { Program Educational } \\
\text { Objective }\end{array}$ & Buffalo State College & $\begin{array}{l}\text { Rochester Institute of } \\
\text { Technology }\end{array}$ & $\begin{array}{l}\text { University of Pittsburgh } \\
\text { at Johnstown }\end{array}$ \\
\hline $\begin{array}{l}\text { Attained employment in } \\
\text { the field. }\end{array}$ & Yes & Yes & Yes \\
\hline $\begin{array}{l}\text { Pursued Additional } \\
\text { Formal Education and / } \\
\text { or certification }\end{array}$ & Not as such. & Yes & $\begin{array}{l}\text { Stated as offering } \\
\text { opportunities at UPJ - } \\
\text { "lifelong learning } \\
\text { process” }\end{array}$ \\
\hline $\begin{array}{l}\text { Attained increasing } \\
\text { levels of responsibility } \\
\text { and leadership in their }\end{array}$ & Professional Success & Yes & $\begin{array}{l}\text { As part of a basic } \\
\text { principle - "grow and } \\
\text { develop” }\end{array}$ \\
\hline
\end{tabular}

Proceedings of the 2005 American Society for Engineering Education Annual Conference \& Exposition Copyright (C) 2005, American Society of Engineering Education 


\begin{tabular}{|l|l|l|l|}
\hline chosen field. & Part of a PO, not a PEO & Part of a PO, not a PEO. & Yes \\
\hline $\begin{array}{l}\text { Ethical standards } \\
\text { directed toward solving } \\
\text { technological problems } \\
\text { of industry and society. }\end{array}$ & Part of a PO, not a PEO & Part of a PO, not a PEO. & Yes \\
\hline Human Relations Skills & $\begin{array}{l}\text { Alumni and employer } \\
\text { survey every six years }\end{array}$ & $\begin{array}{l}\text { Several measurements } \\
\text { in Alumni Survey done } \\
\text { every 6 years. }\end{array}$ & $\begin{array}{l}\text { Alumni and employer } \\
\text { survey every six years. }\end{array}$ \\
\hline Measurements & Survery \\
\hline
\end{tabular}

\section{Program Outcomes (PO’s)}

TAC of ABET defines a program outcome as an action which a student demonstrates upon graduation from an accredited program. TAC of ABET defines a set of program outcomes (a-k) which each program must obtain and a set of program criteria for each of the various programs. Each program can define its own program outcomes, so long as it maps them to the general (a-k) and specific program criteria. The following table is a quick summary of the program outcomes defined by the three universities.

\begin{tabular}{|c|c|c|c|c|}
\hline $\begin{array}{l}\text { ABET } \\
\text { Definition }\end{array}$ & General Category & BSC & RIT & UPJ \\
\hline & & $\begin{array}{l}\text { From ABET } \\
\text { Self Study }\end{array}$ & $\begin{array}{l}\text { From ABET } \\
\text { Self Study }\end{array}$ & $\begin{array}{l}\text { From Continuous } \\
\text { Improvement Plan }\end{array}$ \\
\hline $\mathrm{a}$ & $\begin{array}{l}\text { Mastery of Knowledge in } \\
\text { Technical Fields }\end{array}$ & Yes & Yes & Yes \\
\hline b & $\begin{array}{l}\text { Apply Knowledge in Technical } \\
\text { Fields }\end{array}$ & Yes & Yes & \\
\hline C & Experimentation & Yes & Yes & Yes \\
\hline $\mathrm{d}$ & Creativity in design & Yes & Yes & \\
\hline $\mathrm{e}$ & Work in Teams & Yes & Yes & Yes \\
\hline $\mathrm{f}$ & Solve Technical Problems & Yes & Yes & \\
\hline g & Communicate Effectively & Yes & Yes & Yes \\
\hline h & Lifelong Learning & Yes & Yes & \\
\hline $\mathrm{i}$ & Professional, Ethical and Social & Yes & Yes & Yes \\
\hline $\mathrm{j}$ & Diversity and World Issues & Yes & Yes & Yes \\
\hline $\mathrm{k}$ & Quality, timeliness, CIP & Yes & Yes & \\
\hline Program Criteria & Circuits, programming, etc. & Yes & Yes & \\
\hline “ & Apply Physics / Chemistry & Yes & Yes & \\
\hline “" & Depth \& Breadth & Yes & Yes & Yes \\
\hline “ & Various EET Fields & Yes & Yes & \\
\hline “ & Project Management & Yes & Yes & \\
\hline “ & Math beyond Calculus & Yes & Yes & \\
\hline Institutional & & N/A & N/A & \\
\hline
\end{tabular}

Note: Those categories which have not been checked in these tables are ones which UPJ has not specifically called out in their internal CIP process. They will be preparing for a TC2K visit in the near future.

Conclusions from PEO’s and PO’s:

It is obvious that each EET program has to meet ABET standards, and from the first two tables they have met these minimum standards for the programs.

There were not particular institutional PEO or PO statements which would alter individual programs or courses at the respective universities. 
Since this paper will focus particularly the power system required or elective courses, it is now time to look at the specifics of three sets of courses in power systems: electric machines, power systems and power electronics. In each case, there may be more than one course in a given area but we will lump the courses into these three categories.

In each of the three areas, there are also three items worth investigating. The first is what many who have written TAC of ABET self studies would call course outcomes or intended learning objectives. The second is the set of topics included in each area. The third is the laboratory exercises included (if any) in each course.

Part of the exercise of preparation for ABET is to be as specific as possible, without listing items that cannot or will not be measured. While some of the items are certainly included in a course, they are not stated because they are not going to be measured in the particular course at the particular institution. Where "Not stated" is used, the material may well be covered, but not measured for ABET purposes.

Electric Machines

\begin{tabular}{|l|l|l|l|}
\hline Electric Machines Course Outcomes & BSC & RIT & UPJ \\
\hline Identify types, characteristics and components & Yes & Not stated & Yes \\
\hline Convert transformers and machines to circuit models & Not stated & Yes & Yes \\
\hline Measure the electrical and mechanical parameters & Yes & Yes & Yes \\
\hline Specify motors, generators and transformers & Yes & Yes & Yes \\
\hline Work in teams to build, troubleshoot and analyze devices. & Not stated & Yes & Yes \\
\hline Obtain / compare data to theory. & Yes & Yes & Yes \\
\hline Compare electrical and mechanical quantities & Yes & Yes & Yes \\
\hline Good written report & Yes & Not stated & Not stated \\
\hline Technical Literacy and Lifelong Learning & Yes & Not stated & Not stated \\
\hline Role and limitations of technology & Yes & Not stated & Yes \\
\hline
\end{tabular}

\begin{tabular}{|l|l|l|l|}
\hline Electric Machines Topical Content & BSC & RIT & UPJ \\
\hline Review of Circuits & Yes & Yes & Yes \\
\hline Transformer Parameters and specifications & Yes & Yes & Yes \\
\hline Ideal and realistic transformers & Yes & Yes & Yes \\
\hline $\begin{array}{l}\text { Transformer parameters referred to high side and } \\
\text { low side. }\end{array}$ & Yes & Not stated & Yes \\
\hline Rotating Magnetic Field & Yes & Yes & Yes \\
\hline Induction Motor Principles & Yes & Yes & Yes \\
\hline $\begin{array}{l}\text { Squirrel Cage and Wound Rotor3 Phase Induction } \\
\text { Motors }\end{array}$ & Yes & Yes & Yes \\
\hline Single Phase Induction Motors & Yes & Yes & Yes \\
\hline Speed and torque control of induction motors & Yes & Not stated & Yes \\
\hline Solid State motor controls & Yes & No & Yes \\
\hline Fractional HP motors, application and types & Yes & Yes & Yes \\
\hline Stepper Motors \& controls & Yes & Yes & No \\
\hline Synchronous Motors and generators & Yes & Yes & Yes \\
\hline Rotor Types & Yes & Yes & Yes \\
\hline Power Factor Correction with SM & Yes & Not Stated & Yes \\
\hline Synchronous Machine Power Angle & Yes & Yes & Yes \\
\hline Efficiency & Yes & Yes & Yes \\
\hline $\begin{array}{l}\text { Industrial Applications: specifications - selecting, } \\
\text { sizing. }\end{array}$ & Yes & Not Stated & Yes \\
\hline DC Machines & Not Stated & Yes & Yes \\
\hline
\end{tabular}

Proceedings of the 2005 American Society for Engineering Education Annual Conference \& Exposition Copyright (c) 2005, American Society of Engineering Education 


\begin{tabular}{|l|l|l|l|}
\hline Electric Machines Laboratory Topics & BSC & RIT & UPJ \\
\hline 3 Phase AC Circuits & Not stated & Yes & Yes \\
\hline 3 Phase Power \& Phase Sequence & Not stated & Yes & Yes \\
\hline Transformer, Motor \& Generator Testing Procedures & Yes & Yes & Yes \\
\hline Instrumentation for Testing & Yes & Yes & Yes \\
\hline Simulation Software & Yes & Not Stated & Yes \\
\hline $\begin{array}{l}\text { Single Phase Transformer parameters and voltage } \\
\text { regulation }\end{array}$ & Yes & Yes & Yes \\
\hline Wound-Rotor induction motor & Yes & Yes & Yes \\
\hline Squirrel cage induction motor & Yes & Yes & Yes \\
\hline Synchronous Motor and Generator & Yes & Yes & Yes \\
\hline DC machines & Not stated & Yes & Yes \\
\hline
\end{tabular}

Power Systems

\begin{tabular}{|c|c|c|c|}
\hline Power Systems Course Outcomes & BSC & RIT & UPJ \\
\hline Distinguish the elements of a power system. & Yes & Yes & Yes \\
\hline Solve balanced and unbalanced 3 phase circuits & Yes & Yes & Yes \\
\hline $\begin{array}{l}\text { Solve power factor correction problems and apply various methods } \\
\text { of controlling switched capacitors. }\end{array}$ & Yes & Yes & Yes \\
\hline Find $60 \mathrm{~Hz}$ transmission line impedances & Yes & Yes & Yes \\
\hline $\begin{array}{l}\text { Apply various substation configurations, including placement of } \\
\text { instrument transformers. }\end{array}$ & Implied & Yes & Yes \\
\hline Determine the efficiency and voltage regulation of a transformer. & $\begin{array}{l}\text { See } \\
\text { Machines }\end{array}$ & Yes & Yes \\
\hline $\begin{array}{l}\text { Design and present the electrical layout of an industrial facility, city } \\
\text { or region. }\end{array}$ & $\begin{array}{l}\text { Industrial } \\
\text { Facility }\end{array}$ & Yes & No \\
\hline Apply basic criteria to troubleshoot for power quality & Yes & Yes & No \\
\hline $\begin{array}{l}\text { Write a paper on electric power systems, using significant } \\
\text { references from technical magazines. }\end{array}$ & Yes & Yes & No \\
\hline Solve a load flow for a power system. & Yes & Yes & Yes \\
\hline Solve a simple economic operation problem with two generators. & No & Yes & Yes \\
\hline Determine line fault currents using symmetrical components. & Yes & Yes & Yes \\
\hline $\begin{array}{l}\text { Use the equal area criterion to determine the stability of a power } \\
\text { system. }\end{array}$ & Yes & Yes & No \\
\hline $\begin{array}{l}\text { Apply electromechanical and solid state relays to simple power } \\
\text { systems. }\end{array}$ & Yes & Yes & Yes \\
\hline $\begin{array}{l}\text { Include concepts of supervisory control and telemetry in the study } \\
\text { of power systems. }\end{array}$ & Implied & Yes & Yes \\
\hline $\begin{array}{l}\text { Do a class projects utilizing load flow, protective relaying and } \\
\text { system faults. }\end{array}$ & Yes & Yes & Yes \\
\hline $\begin{array}{l}\text { Historical development of power systems to include effects of } \\
\text { deregulation. }\end{array}$ & Yes & Implied & No \\
\hline Per Unit Analysis & Yes & Implied & Yes \\
\hline Simple Fault Analysis without symmetrical components. & Yes & No & Yes \\
\hline Economics of Power Distribution & Yes & No & Yes \\
\hline Lifelong learning skills. & Yes & Implied & Implied \\
\hline $\begin{array}{l}\text { Role and limitations of technology and need of responsible } \\
\text { application of technology. }\end{array}$ & Yes & Implied & Implied \\
\hline Demand Management and its calculations & Yes & No & No \\
\hline
\end{tabular}




\begin{tabular}{|l|l|l|l|}
\hline Power Systems Topical Content & BSC & RIT & UPJ \\
\hline Review of single phase power & No & Optional & No \\
\hline Basic Elements of Power System & Yes & Yes & Yes \\
\hline Balanced and unbalanced 3 Phase & Yes & Yes & Yes \\
\hline Capacitors and PF Correction & Yes & Yes & Yes \\
\hline Transmission Line configurations and impedances & Yes & Yes & Yes \\
\hline Transformers, autotransformers and 3 phase transformers & Yes & Yes & Yes \\
\hline Per Unit System, system parameters & Yes & Yes & Yes \\
\hline Load management and energy conservation & Implied & Yes & Yes \\
\hline Substation Layout & Yes & Yes & Yes \\
\hline Metering and Instrument Transformers & Yes & Yes & Yes \\
\hline Power Reliability and Quality & Yes & Yes & Yes \\
\hline Class Project - Layout of a power system & Yes & Yes & Yes \\
\hline Library project and oral presentation & Yes & Yes & No \\
\hline Load flow - equations and simulation & Yes & Yes & Yes \\
\hline Economic Operation - 2 Generators & No & Yes & Yes \\
\hline Fault Analysis with symmetrical components & Yes & Yes & Yes \\
\hline System stability - equal area criterion & Yes & Yes & No \\
\hline System protection, using EM and SS relays & Yes & Yes & Yes \\
\hline Supervisory Control and Telemetry & Yes & Yes & Yes \\
\hline Capstone class project & Yes & Yes & No \\
\hline $\begin{array}{l}\text { Historic development of power systems to include effects } \\
\text { of deregulation }\end{array}$ & Yes & Implied & No \\
\hline
\end{tabular}

\begin{tabular}{|l|l|l|l|}
\hline Power Systems Laboratory Content & BSC & RIT & UPJ \\
\hline 30 degree phase shift in 3-phase transformers & Yes & Yes & Yes \\
\hline Characteristics of Time Over-Current Relay & $\begin{array}{l}\text { Not at this } \\
\text { time }\end{array}$ & $\begin{array}{l}\text { Not at this } \\
\text { time } \\
\text { (NATT) }\end{array}$ & Yes \\
\hline Simulations of Faults and Load Flow & Yes & Yes & Yes \\
\hline Characteristics of Directional Over-Current Relays & NATT & NATT & Yes \\
\hline Characteristics of Differential Relays & NATT & NATT & Yes \\
\hline Characteristics of Reverse Power Relays & NATT & NATT & Yes \\
\hline $\begin{array}{l}\text { Tour local power generation and industrial plant with large } \\
\text { power systems in place }\end{array}$ & Yes & NATT & Yes \\
\hline $\begin{array}{l}\text { Use of Simulation Software: Power World Simulator, SKM } \\
\text { Analysis }\end{array}$ & Yes & NATT & Yes \\
\hline Protective Relay Coordination Studies & NATT & NATT & Yes \\
\hline
\end{tabular}

Note: Lab content is being revised at Buffalo State as a result of Schweitzer Engineering Laboratories equipment donation.

Power Electronics

\begin{tabular}{|l|l|l|l|}
\hline Power Electronics Course Outcomes & BSC & RIT & UPJ \\
\hline $\begin{array}{l}\text { Describe the characteristics of power semiconductor } \\
\text { devices }\end{array}$ & Yes & NATT & Yes \\
\hline $\begin{array}{l}\text { Demonstrate the principles of operation of static power } \\
\text { conversion }\end{array}$ & Yes & NATT & Yes \\
\hline $\begin{array}{l}\text { Specify appropriate pulse-width modulation techniques for } \\
\text { voltage and frequency control. }\end{array}$ & Yes & NATT & Yes \\
\hline $\begin{array}{l}\text { Select and design an appropriate technique of Thyristor } \\
\text { commutation for an industrial application }\end{array}$ & Yes & NATT & Yes \\
\hline
\end{tabular}

Proceedings of the 2005 American Society for Engineering Education Annual Conference \& Exposition Copyright (c) 2005, American Society of Engineering Education 


\begin{tabular}{|l|l|l|l|}
\hline Power Electronics Course Outcomes & BSC & RIT & UPJ \\
\hline $\begin{array}{l}\text { Relate the advantages and disadvantages of various } \\
\text { conversion topologies. }\end{array}$ & Yes & NATT & Yes \\
\hline $\begin{array}{l}\text { Design a power electronics circuit for an industrial } \\
\text { application. }\end{array}$ & Yes & NATT & Yes \\
\hline $\begin{array}{l}\text { Analyze the designs and apply design considerations for } \\
\text { several power electronic circuits }\end{array}$ & Yes & NATT & Yes \\
\hline
\end{tabular}

\begin{tabular}{|l|l|l|l|}
\hline Power Electronics Topical Content & BSC & RIT & UPJ \\
\hline $\begin{array}{l}\text { Applications of power electronics, and types of power } \\
\text { electronic circuits }\end{array}$ & Yes & NATT & Yes \\
\hline Characteristics of diodes and power semiconductor diodes & Yes & NATT & Yes \\
\hline Diode Rectifiers: single and three phase rectifiers & Yes & NATT & Yes \\
\hline $\begin{array}{l}\text { Thyristors: Characteristics of silicon-controlled rectifiers, } \\
\text { gate-turn-off thyristors and MOS-controlled thyristors }\end{array}$ & Yes & NATT & Yes \\
\hline $\begin{array}{l}\text { Controlled Rectifiers: Single phase converters and dual } \\
\text { converters }\end{array}$ & Yes & NATT & Yes \\
\hline $\begin{array}{l}\text { AC Voltage Controllers: Single-phase and three-phase } \\
\text { converters }\end{array}$ & Yes & NATT & Yes \\
\hline $\begin{array}{l}\text { Power Thyristors: Characteristics of power BJTs, } \\
\text { MOSFETs and IGBTs }\end{array}$ & Yes & NATT & Yes \\
\hline DC Choppers: step-down and step-up operation & Yes & NATT & Yes \\
\hline $\begin{array}{l}\text { Pulse-Width Modulated Inverters: Single-phase, three- } \\
\text { phase inverters, voltage control of inverters, and current } \\
\text { source inverters }\end{array}$ & Yes & Yes \\
\hline $\begin{array}{l}\text { Resonant-Pulse Inverters: Series-resonant and parallel- } \\
\text { resonant inverters }\end{array}$ & Yes & NATT & No \\
\hline
\end{tabular}

\begin{tabular}{|l|l|l|l|}
\hline Power Electronics Laboratory Content & BSC & RIT & UPJ \\
\hline Diode characteristics & Yes & NATT & Yes \\
\hline Diode rectifiers & Yes & NATT & Yes \\
\hline Thyristor circuits & Yes & NATT & Yes \\
\hline Thyristor controlled circuits & Yes & NATT & Yes \\
\hline Single-phase converters & Yes & NATT & Yes \\
\hline Three-phase converters & Yes & NATT & Yes \\
\hline Single-phase inverters & Yes & NATT & Yes \\
\hline Three-phase inverters & Yes & NATT & Yes \\
\hline
\end{tabular}

Continuous Improvement Model and Systems Approach

The authors utilized systems engineering principles [1] to the proposed model. These principles are:

- Decomposition and functional analysis

- Requirements or criteria

- Synthesis

- Testing

- Communications

Iterative top-down decomposition is utilized to the subject matter itself and results in topical outlines presented in the previous section. This process reflects actual engineering procedures and operations found in design and operations of electric power systems.

Proceedings of the 2005 American Society for Engineering Education Annual Conference \& Exposition Copyright (c) 2005, American Society of Engineering Education 
Requirements or criteria must be measurable, should be monitored throughout further steps of analysis, and could be optimized. Besides technical and economical requirements found in any engineering system the criteria specified in ABET Criterion 2 for program outcomes are also utilized.

With topical outlines known it is possible to propose an advanced curriculum based on interrelations between topics of different disciplines within Electrical Engineering Technology (EET) program, between EET and other programs, and between courses and programs in different institutions.

Communications are utilized through direct connections between blocks as well as feedback loops.

Figure 1 shows the diagram of proposed methodology.

The authors modified the process proposed in [2] by specifying the content of each block and adding additional feedback loop.

Program goals, program educational objectives, and suggestions from Industrial Advisory Boards are viewed as an intellectual input to continuous improvement program (CIP). Program outcomes are viewed as a process, while topical outlines are the output of the CIP and course outcomes are considered to be the outcomes of the CIP.

Conditions, such as faculty, facilities, equipment, institutional and external support, are treated as physical input to the CIP.

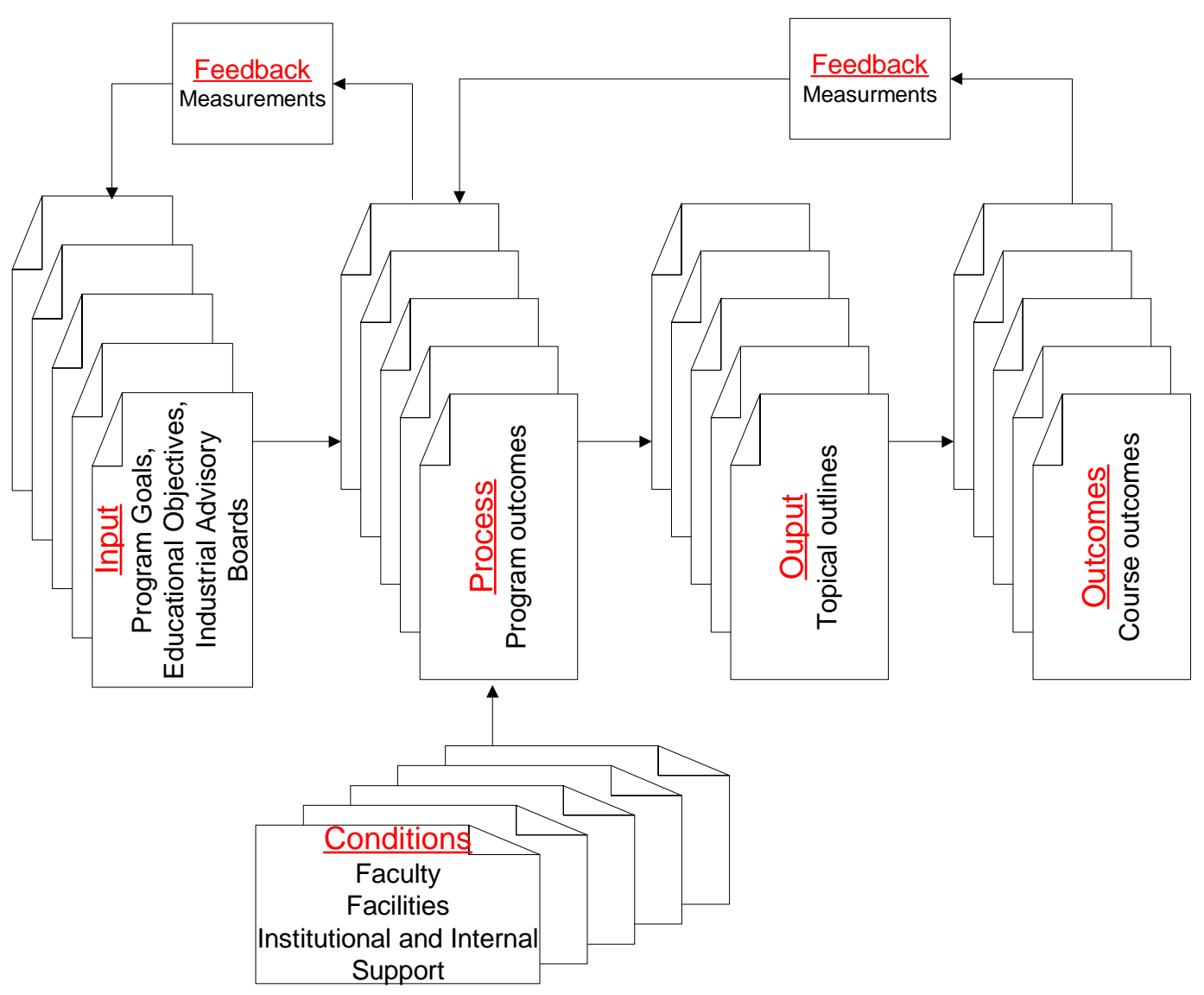

Figure 1. Continuous Improvement Program Diagram 
There are two feedback loops: the process (program outcomes) could be modified as a result of measurable feedback from course outcomes. The input (program goals and objectives) could also be modified as a result of modifications in program outcomes. It is also clear that the amount of internal and external support, available equipment, state of facilities, and qualifications of faculty members provide unique input to the process and are responsible for diverse output and outcomes. As an example, an ability of University of Pittsburgh in Johnstown to acquire power systems simulator led to a variety of laboratory and lecture topics to be introduced. Similarly, acquisition of power electronics set of modules by LabVolt allowed Buffalo State College to offer a senior elective laboratory course in this discipline. Likewise, recent donation of digital relays set by Schweitzer Engineering Laboratories to Buffalo State changed topical outlines and added laboratory experiments to their power systems and other EET courses.

In Fig. 1 multiple documents reflect different programs, such as EET, MET, and other programs within Engineering Technology as well as outside the unit itself. Business, Computer Information Systems, Creative Studies, Math and Physics are among them. All these layers should be coordinated as well for optimal course and program outcomes. The same is true for coordination between institutions. In this case CIPs of each participating institution should be synthesized to provide for a better process. Coordination and consultations between different entities is important and provides benefits to the profession despite organizational structure in different institutions.

What Have The Author's Found?

1. The requirements by ABET for preparation to better document student outcomes, course content and laboratory content has allowed this kind of comparison to be done.

2. Different institutions will naturally have somewhat different courses in the same general area. Such differences come from interaction with industrial advisory committees, input from graduates, and the expertise of the instructors. Additional differences will come from the number of courses allocated by the EET curriculum to required power courses and to technical electives available to the students.

3. While the course content may be similar between institutions, the course student outcomes may be written differently. Some institutions may rely on the power courses to demonstrate areas like lifelong learning, impact of technology on society and capstone experiences, others may use alternate courses to fulfill these requirements.

4. Areas like an understanding of lifelong learning and ethics might also be measured by a PEO rather than just a PO, as now used by TAC of ABET.

5. Project Management is not now taught in the power courses, but this is a possible use for it in EET curricula.

6. A survey such as this one can help an institution justify better laboratory equipment and more power electives in its curriculum.

\section{Conclusions}

Institutions can learn by comparing their courses with others whose mission is similar. After consultation with industrial advisory boards and alumni, the faculty may choose to alter their current courses. Such consultation and thought can result in very significant changes in courses, or may only result in minor changes.

The three institutions who have participated in this study will make such decisions over the next year or two, but it will take a few years for course changes and equipment purchases to impact their curricula. Some institutions may choose not to make significant changes, but to evolve their curricula into what their constituencies will recommend.

The authors have concluded that yet another influential input besides IABs and alumni should be in the form of consultations between institutions with similar programs. Creating a consortium (regional or even broader) of institutions with power-related programs would serve this purpose well, although other forms of cooperation are possible. 
Bibliography

1. Grinberg I., Stratton J. A Systems Engineering Approach to Engineering Design Methodology, Journal of Engineering Technology, Fall 1996, pp. 8- 13

2. Gregory Neff and Susan Scachitti. "Continuous Improvement of Engineering Technology Programs --Coming Soon to a University Near You”, Proceedings of 2000 Annual Conference of the American Society for Engineering Education, Montreal St. Louis, Missouri June 18-21, 2000

ILYA Y. GRINBERG

Ilya Grinberg graduated from the L'viv Polytechnic Institute (L'viv, Ukraine) with an MS in EE and earned a Ph.D. degree from the Moscow Institute of Civil Engineering (Moscow, Russia). He has over 30 years of experience in design and consulting in the field of power distribution systems and design automation. Currently he is Professor of Engineering Technology at Buffalo State College. He is a Senior Member of IEEE, and a member of ASEE.

\section{JOHN A. STRATTON}

John A. Stratton graduated from the Rochester Institute of Technology (RIT) with a BS and Rensselaer Polytechnic Institute with an MS in EE in 1964 and 1966 respectively. Currently he is Professor of Engineering Technology at RIT. He is a Senior Member of the IEEE and a member of the ASEE.

\section{FRANK W. PIETRYGA}

Frank W. Pietryga is an Assistant Professor at the University of Pittsburgh at Johnstown. He graduated from UPJ in 1983 with a BSEET degree and completed his MSEE degree in 1993 at the University of Pittsburgh, main campus. His interests include power system engineering, AC/DC machinery, power electronics, and motor drive systems. Mr. Pietryga is also a registered professional engineer in the Commonwealth of Pennsylvania

\section{JAMES MAXVELL}

James Maxwell is a Professor and Chair of the Business Department at Buffalo State College. He holds a Ph.D. in Management from Webster University, St. Louis, Missouri, a MBA and BS in Management from Maryville University, St. Louis, Missouri. He is currently completing a Ph.D. in Technology Management in Indiana State University, Terre Haute, Indiana. He serves on editorial boards for several business and management journals. 